\title{
ACOUSTIC IDENTIFICATION AND TAXONOMIC REMARKS OF HIPPOSIDERIDS AND RHINOLOPHIDS (Chiroptera: Hipposideridae, Rhinolophidae) IN TAM DAO NATIONAL PARK, NORTHEASTERN VIETNAM
}

\author{
Vu Dinh Thong
}

Institute of Ecology and Biological Resources, VAST, vietnambat@ gmail.com

\begin{abstract}
Hipposiderids and rhinolophids are referred to all taxa of the two families Hipposideridae and Rhinolophidae, respectively. Their echolocation signals are diagnostic by a dominant "constant frequency" (CF) segment. Each echolocation signal of leaf-nosed bat species consists of two segments ("constant-frequency" and "terminal frequency-modulated") while that of horseshoe bat species comprises three segments ("initial frequency-modulated", "constantfrequency" and "terminal frequency-modulated"). Between 2008 and 2014, a series of field surveys was conducted in Tam Dao National Park (TDNP) with particular emphases on taxonomy and echolocation of CF bat species. Results from the surveys indicated that TDNP is a home to three species of Hipposideridae (Hipposideros armiger, H. larvatus and H. pomona) and five species of Rhinolophidae (Rhinolophus affinis, R. luctus, R. macrotis, R. pearsonii and $R$. pusillus). During the present study, $R$. luctus was only detected in the field based on a poor echolocation call while all seven remaining species were captured. The $\mathrm{CF}$ of the second harmonic and morphological features of each species are clearly distinguished from the respective ones of the remaining species. This paper provides the external and acoustic diagnoses of each species for identification in the field to strengthen survey achievements, monitoring and conservation of CF bats in the park in coming time.
\end{abstract}

Keywords: Echolocation, conservation, Mammalia, monitoring, taxonomy.

\section{INTRODUCTION}

To date, Hipposideridae comprises 89 species belonging to 17 genera [23] and Rhinolophidae comprises 89 monogeneric species worldwide $[2,6,8,16,17,19,26,27$, 28, 29, 30]. In Vietnam, hipposiderids consist of 19 species belonging to three genera: Aselliscus, Coelops and Hipposideros [3, 5, 11, 16, 21, 21, $25]$ and rhinolophids consist of 16 species [21].

Among the current protected area system of Vietnam, TDNP is one of the most well known parks for all tourism, biodiversity research and conservation. Prior to the present study, a series of field surveys were carried out in the park [Error! Reference source not found.]. Between 2006 and 2014, the author conducted 6 field surveys throughout the park. Results from the surveys provided taxonomic materials and echolocation data of three hipposiderid and five rhinolophid species. Echolocation calls of these species are specific to species. Several of the recorded species were rarely captured but possibly detected by echolocation calls in the field. This paper provides remarks on their diagnoses in both morphology and echolocation to maximize achievements of forthcoming research, monitoring and conservation actions in coming time.

\section{MATERIALS AND METHODS}

\section{Bat capture and identification}

For a confirmation of hipposiderid and rhinolophid diversity within TDNP, field surveys were conducted at forested areas, which were previously surveyed with records bat species [Error! Reference source not found.]. Bats were captured and handled in the field following the guidelines approved by the American Society of Mammalogists [15]. Fourbank harp traps [8] and mist nets of various sizes (2.6 $\mathrm{m}$ [height], 3-12 $\mathrm{m}$ [length], mesh size: $16 \mathrm{~mm} \times 16 \mathrm{~mm}$ ) were employed to capture bats. Each captured bat was removed carefully from the trap or net and placed individually in a cotton bag. Their external 
measurements were taken following Bates \& Harrison (1997) [1], Csorba et al. (2003) [6], Vu Dinh Thong (2011) [21] and Vu Dinh Thong et al. $(2012,2012,2012)$ [23, 24, 25]. The measurements comprise FA, forearm lengthfrom the extremity of the elbow to the extremity of the carpus with the wings folded; $\mathrm{EH}$, ear height-length of ear conch; TIB, tibia lengthfrom the knee joint to the ankle; HF, hind-foot length-from the extremity of the heel behind the os calcis to the extremity of the longest digit, excluding the hairs or claws; Tail: tail length, from the tip of the tail to its base adjacent to the body. Reproductive status and age were assessed following Racey (2009) [14] and Brunet-Rossinni and Wilkinson (2009) [4], respectively. To reduce the influence of seasonal variations in body mass, juveniles and pregnant females were excluded from analyses.

\section{Echolocation recordings and analyses}

Echolocation calls were obtained from recordings in four situations: handheld, inside a flight-tent $(4 \mathrm{~m}$ [length] $\times 4 \mathrm{~m}$ [width] $\times 2 \mathrm{~m}$ [height]) and hand release using a PCTape system at a sampling rate of $480 \mathrm{kHz}$. Batman software, which displays color sonagrams of the detected echolocation signals in real time, was used to obtain high quality sound sequences. Additionally, continuous recordings were also carried out in front of caves and under forest canopies to obtain echolocation calls when bats were leaving their roosts and foraging in natural habitat, respectively. All echolocation signals from manual and continuous recordings were analysed using Selena software to measure the constant frequency of the second harmonic (CF2) of each call. The PCTape system, Batman and Selena softwares are custom-made by the University of Tübingen, Germany.

\section{RESULTS AND DISCUSSION}

\section{Identity and echolocation frequency of each species}

Hipposideros armiger: This is a large species of Hipposideros. An average forearm length of the four captured females from TDNP is $93.0 \mathrm{~mm}(91.6-95.4 \mathrm{~mm})$. Its noseleaf has four supplementary leaflets. Of which, the outmost one is less developed and much smaller than the three remainders (fig. 1A). Each echolocation signal consists of two segments, namely "constant" (CF) and "terminal frequency-modulated" (tFM) (fig. 2A). Frequency value range for $\mathrm{CF} 2$ of the captured individuals is $64.9-65.9 \mathrm{kHz}$.

Hipposideros larvatus: This is a mediumsized species of Hipposideros. The forearm lengths of one female and one male captured from TDNP are $57.7 \mathrm{~mm}$ and $58.1 .0 \mathrm{~mm}$, respectively. The noseleaf of each individual has three supplementary leaflets, which are almost equal in size (fig. 1B). Each echolocation signal consists of two segments, namely $\mathrm{CF}$ and tFM (fig. 2B). Frequency values for $\mathrm{CF} 2$ of the captured female and male are 88.2 and $85.9 \mathrm{kHz}$, respectively.

Hipposideros pomona. This is a small species of Hipposideros. The forearm lengths of one female and one male captured from TDNP are $42.1 \mathrm{~mm}$ and $41.8 \mathrm{~mm}$, respectively. The noseleaf structure of each individual is simple without supplementary leaflet (fig. 1C). Each echolocation signal consists of two segments, namely $\mathrm{CF}$ and tFM (fig. 2C). Frequency values for $\mathrm{CF} 2$ of the captured individuals are 128.2 and $129.1 \mathrm{kHz}$, respectively.

Rhinolophus affinis: This is a medium-sized species of Rhinolophus. Three females and two males were captured at TDNP during the present study. An average of forearm length of these individuals is $51.4 \mathrm{~mm}(50.4-52.5 \mathrm{~mm})$. The horseshoe is broad but does not cover the whole respective muzzle (fig. 3A). The connection process is rounded and haired sparsely. The lancet has two straight sides with a pointed tip. There are three vertical grooves on the lower lip. The pinna is small with a height of 20.00-22.00 mm. Each echolocation signal comprises three segments, namely "initial frequency-modulated" (iFM), CF and tFM (fig. 4A). An average value of frequency for CF2 of the five captured individuals is $73.5 \mathrm{kHz}$ (72.9$73.8 \mathrm{kHz}$ ).

Rhinolophus macrotis: This is a small and uncommon species of Rhinolophus. The forearm length of one captured individual from 
TDNP is $39.74 \mathrm{~mm}$. The horseshoe is broad and covers the whole muzzle (fig. 3B). The connection process is highly haired with a blunt tip. The lancet has two convex sides with a rounded tip. There are three vertical grooves on the lower lip. The pinna is large (in comparison with the body size) with a height of $22.5 \mathrm{~mm}$. Each echolocation signal comprises three segments, namely iFM, CF and tFM (fig. 4B). Frequency value for CF2 is $78.0 \mathrm{kHz}$.
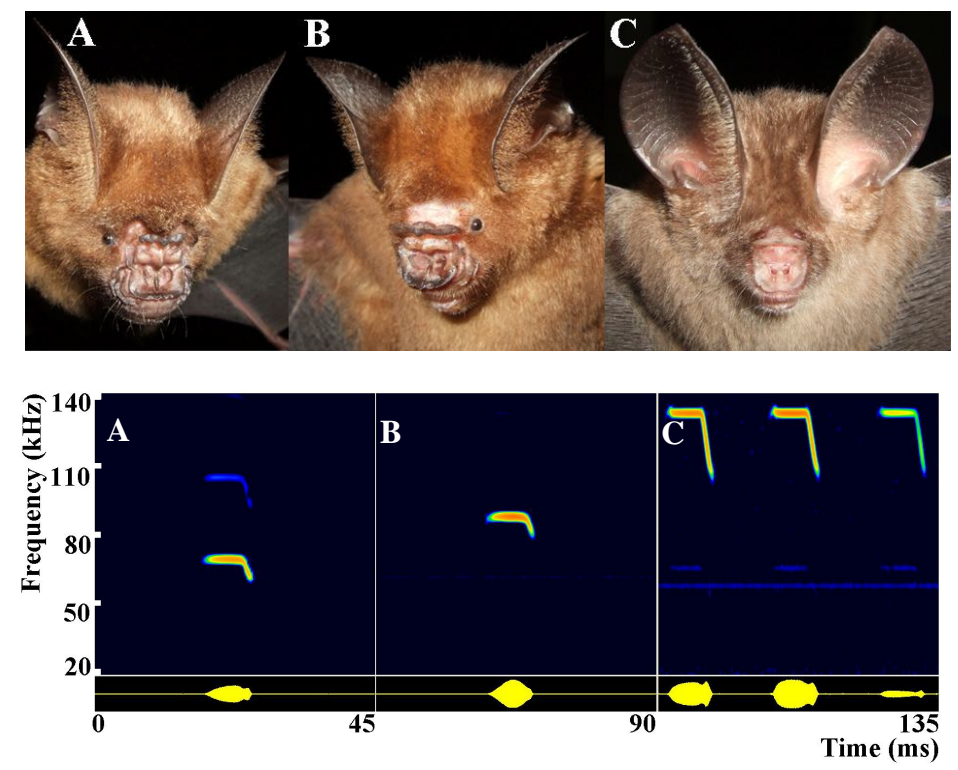

Figure 1. Ear and face of leafnosed bat species from TDNP

\section{A. Hipposideros armiger; B. $H$. larvatus; C. H. pomona.}

Figure 2. Typical echolocation signals of leaf-nosed bat species from TDNP

A. Hipposideros armiger; B. H. larvatus; C. H. pomona.

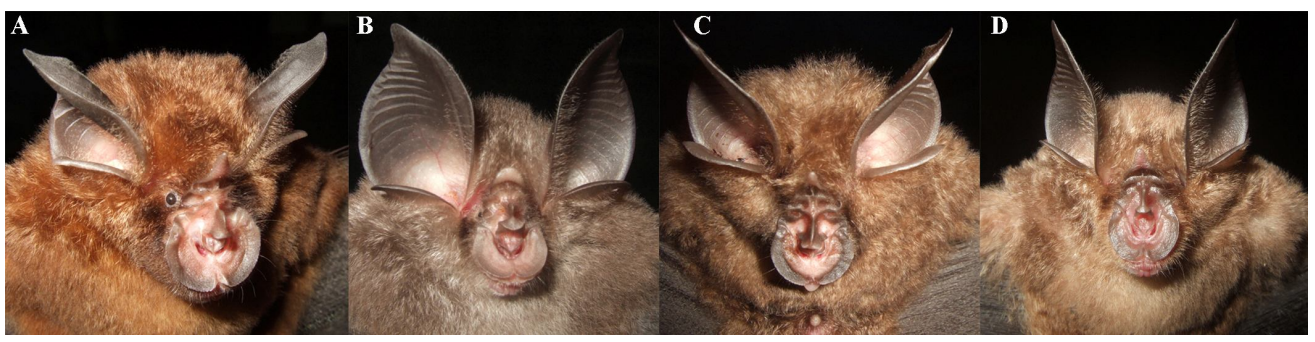

Figure 3. Ear and face of horseshoe bat species from TDNP

A. Rhinolophus affinis; B. R. macrotis; C. R. pearsonii; D. R. pusillus.

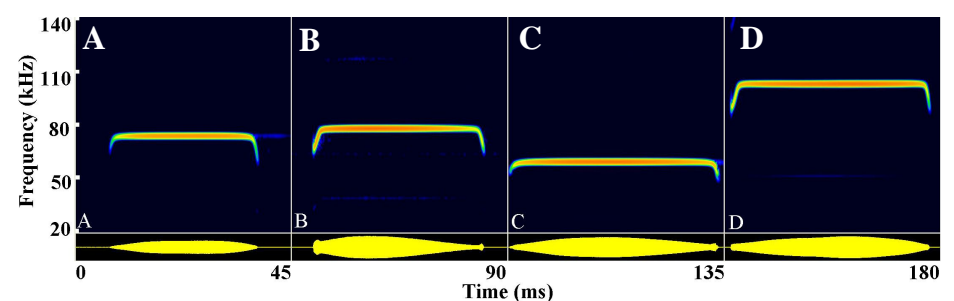

Figure 4. Typical echolocation signals of horseshoe bat species from TDNP

A. Rhinolophus affinis; B. R. macrotis; C. R.pearsonii; D. R.pusillus.

Rhinolophus pearsoni: This is a mediumsized species of Rhinolophus. Three females and two males were captured at TDNP during the present study. An average of forearm length of these individuals is $52.0 \mathrm{~mm}(49.0-53.4 \mathrm{~mm})$.
The horseshoe is broad and covers the whole respective muzzle (fig. 3C). The connection process is low and rounded. The lancet is high with a bluntly pointed tip. There is only one vertical groove on the lower lip. The pinna is 
large with a height of 21.5-26.0 mm. Each echolocation signal comprises three segments, namely iFM, CF and tFM (fig. 4C). An average of frequency values for $\mathrm{CF} 2$ of the captured individuals is $54.4 \mathrm{kHz}(53.7-56.1 \mathrm{kHz})$.

Rhinolophus pusillus: This is a species complex of Rhinolophus. All fourteen females and seven males captured from TDNP are identified as Rhinolophus pusillus since the taxonomy of this species complex is still under discussion worldwide. An average of forearm lengths of these individuals is $37.1 \mathrm{~mm}$ (35.8$39.1 \mathrm{~mm})$. The horseshoe is relatively broad and does not cover the whole respective muzzle (fig. 3D). The connection process is high and normally pointed, forming a "horn-like" in an individual. The lancet is short with a bluntly pointed tip. There are three vertical grooves on the lower lip. The pinna is small with a height of 14.7-18.0 mm. Each echolocation signal comprises three segments, namely iFM, CF and tFM (fig. 4D). An average of frequency values for CF2 of the captured individuals is $105.9 \mathrm{kHz}$ (103.9-110.7 kHz).

\section{DISCUSSION}

Of the horseshoe bats currently known from TDNP, Rhinolophus luctus is rarely captured throughout its distributional range worldwide. Within TDNP, it was only collected by Topal \& Csorba (1992) [20]. During the present study, it was detected from poor echolocation calls in the forest area adjacent to the head quarter of TDNP with a CF2 of $33 \mathrm{kHz}$. This data fit well the echolocation frequency of Rhinolophus luctus from northern Thailand and Lao PDR [18]. In Vietnam, a confirmed distribution of this species covers the following provinces: Son La, Hoa Binh, Ha Tinh, Thua Thien-Hue, Kon Tum, Khanh Hoa and Dong Nai (Kruskop, 2013 [13]; Vu Dinh Thong et al. unpublished data). Borissenko and Kruskop (2003) [3] and Kruskop (2013) [13] mentioned that "the CF component around $110 \mathrm{kHz}$ ". CF2 is the most dominant and specific to species of hipposiderid and rhinolophid bats in Vietnam and in inverse correlation with forearm length [21]. Therefore, the "CF" value in Borissenko and Kruskop (2003) [3] and Kruskop (2013) [13] is questionable and needs a re-examination of the original sound file. According to the poor echolocation signals recorded from TDNP during the present study and published data, a frequency range for CF2 of Rhinolophus luctus must be around $30.0-34.0 \mathrm{kHz}$.

Table 1. A comparison of the $\mathrm{CF} 2$ values (in $\mathrm{kHz}$ ) of hipposiderids and rhinolophids from TDNP and other localities in Vietnam

\begin{tabular}{|c|c|c|c|c|c|}
\hline \multirow[b]{2}{*}{ Species } & \multirow{2}{*}{$\begin{array}{l}\text { Echolocation } \\
\text { signal } \\
\text { structure }\end{array}$} & \multicolumn{4}{|c|}{ Localities } \\
\hline & & TDNP & $\begin{array}{c}\text { Kim Hy nature } \\
\text { reserve* }\end{array}$ & $\begin{array}{c}\text { Cat Ba national } \\
\text { park** }\end{array}$ & Others*** \\
\hline H. armiger & CF-tFM & 64.9-65.9 & $63.2-66.8$ & $\mathrm{n} / \mathrm{a}$ & $62.0,78.0$ \\
\hline H. larvatus & CF-tFM & $85.9-88.2$ & $83.8-89.3$ & $\mathrm{n} / \mathrm{a}$ & $93.0-103.0$ \\
\hline H. pomona & CF-tFM & $128.2-129.1$ & $122.0-127.7$ & $\mathrm{n} / \mathrm{a}$ & $\mathrm{n} / \mathrm{a}$ \\
\hline R. affinis & iFM-CF-tFM & $85.9-88.2$ & $69.5-73.4$ & $73.0-73.8$ & $78.0-90.0$ \\
\hline R. luctus & iFM-CF-tFM & 33.0 & $\mathrm{n} / \mathrm{a}$ & $\mathrm{n} / \mathrm{a}$ & 110 \\
\hline R. macrotis & iFM-CF-tFM & 78.0 & $65.2-67.7$ & $68.8-72.7$ & $51.0-52.0$ \\
\hline R. pearsonii & iFM-CF-tFM & $53.7-56.1$ & $51.1-55.4$ & $53.3-56.3$ & $\mathrm{n} / \mathrm{a}$ \\
\hline R. pusillus & iFM-CF-tFM & 103.9-110.7 & $102.3-106.1$ & $104.7-109.1$ & 110 \\
\hline
\end{tabular}

*: Furey et al. (2009) [10]; **: Vu Dinh Thong (2014) [22]; ***: Kruskop (2013) [13]; (n/a): not available; $\mathrm{iFM}, \mathrm{CF}$, tFM are defined in the section "Results and Discussion".

Echolocation research plays important roles in inventory and taxonomy of bats [10, 25].
Within a protected area, echolocation call frequency is a very helpful parameter for 
identification and monitoring of CF bats [21, 22]. However, in a national or regional scale, bat echolocation frequency is in age and geographic variations $[21,12]$. The CF2 values of hipposiderids and rhinolophids from Tam Dao are more or less similar to those of CF bats from Kim Hy Nature Reserve and Cat $\mathrm{Ba}$ National Park but remarkably different from the ones in Kruskop (2013) [13] (table 1). In fact, acoustic identification of bats requires expert background in bat echolocation research with serious attention to both recordings and examination of sound parameters [22].

\section{CONCLUSION}

Tam Dao National Park is a home to three hipposiderid and five rhinolophid bat species: Hipposideros armiger, H. larvatus, $H$. pomona, Rhinolophus affinis, $R$. luctus, $R$. macrotis, $R$. pearsonii, $R$. pusillus. Their echolocation frequencies and morphological parameters are specific to species with very narrow variations. Therefore, each of these eight species is clearly distinguishable from the remainders in both morphology and echolocation call frequency.

Acknowledgements: This research is funded by the Vietnam National Foundation for Science and Technology Development (NAFOSTED) under grant number 106.11-2012.02. The author is very grateful to Prof. Hans-Ulrich Schnitzler, Dr. Annette Denzinger, Dr. Christian Dietz of the University of Tuebingen, Germany; Dr Paul J. J. Bates and Dr. David L. Harrison of the Harrison Institute, England; Prof. Paul Racey of the University of Exeter, England; Dr. Neil Furey of the Fauna and Flora International (Cambodia); Dr. Tigga Kingston of the Texas Tech University (USA); and to our colleagues at the Institute of Ecology and Biological Resources and other institutions for their help and support.

\section{REFERENCES}

1. Bates P. J. J., Harrison D. L., 1997. Bats of the Indian Subcontinent. Harrison Zoological Museum, Sevenoaks, Kent, United Kingdom, 297 pp.
2. Benda P., Vallo P., 2012. New look on the geographical variation in Rhinolophus clivosus with description of a new horseshoe bat species from Cyrenaica, Libya. Vespertilio, 16: 69-96.

3. Borissenko A. V., Kruskop S. V., 2003. Bats of Vietnam and Adjacent Territories: an identification manual. Joint RussianVietnamese Science and Technological Tropical Centre, Moscow and Hanoi, Russia and Vietnam, $212 \mathrm{pp}$.

4. Brunet-Rossinni A. K., Wilkinson G. S., 2009. Methods for age estimation and the study of senescence in bats. In: Kunz T. H., Parsons S. (eds.) Ecological and Behavioral Methods for the Study of Bats, 2nd edition, Johns Hopkins University Press, Baltimore, pp. 315-325.

5. Corbet G. B., Hill J. E., 1992. The Mammals of the Indomalayan Region. Oxford University Press, Oxford, England, 496 pp.

6. Csorba G., Ujhelyi P., Thomas N., 2003. Horseshoe Bats of the World (Chiroptera: Rhinolophidae). Alana Books, England, 160 pp.

7. Nguyen Xuan Dang, 2005. Rapid assessment of mammals in the Tam Dao National Park. Final report for GTZ Office Vietnam, $71 \mathrm{pp}$.

8. Francis C.M., 1989. A comparison of mist nets and two types of harp traps for capturing bats. Journal of Mammalogy, 70: 865-870.

9. Francis C. M., 2008. A guide to the Mammals of Southeast Asia. Princeton University Press, Princeton, USA, 392 pp.

10. Furey N. M., Mackie I. J., Racey P. A., 2009. The role of ultrasonic bat detectors in improving inventory and monitoring surveys in Vietnamese karst bat assemblages. Current Zoology, 55(5): 327 341.

11. Hendrichsen D. K., Bates P. J. J., Hayes B. D., Walson J. L., 2001. Recent records of bats (Mammalia: Chiroptera) from Vietnam 
with six species new to the country. Myotis, 39:35-199.

12. Ith S., Bumrungsri S., Furey N.M., Bates P. J. J., Wonglapsuwan M., Khan F. A. A., Vu Dinh Thong, Soisook P., Satasook C., Thomas N. M., 2015. Taxonomic implications of geographical variation in Rhinolophus affinis (Chiroptera: Rhinolopgidae) in mainland Southeast Asia. Zoological Studies, 54: 31, 1-29.

13. Kruskop S. V., 2013. Bats of Vietnam: Checklist and an identification manual. Moscow, Russia, 299 pp.

14. Racey P. A., 2009. Reproductive assessment in bats. In: Kunz T.H., Parsons S. (eds.) Ecological and Behavioral Methods for the Study of Bats, 2nd edition, Johns Hopkins University Press, Baltimore, pp. 249-264.

15. Sikes R. S., W. L. Gannon, and the Animal Care and Use Committee of the American Society of Mammalogists, 2011. Guidelines of the American Society of Mammalogists for the use of wild mammals in research. Journal of Mammalogy, 92: 235-253.

16. Simmons N. B., 2005. Order Chiroptera. In: Wilson DE and Reeder DM (eds.) Mammal species of the world: A taxonomic and geographic reference. The Johns Hopkins University Press, Baltimore, 3rd edition, pp. 312-529.

17. Soisook P., Bumrungsri S., Satasook C., Vu Dinh Thong, Bu S. S. H., Harrison D. L., Bates P. J. J., 2008. A taxonomic review of Rhinolophus stheno and R. malayanus (Chiroptera: Rhinolophidae) from continental South-East Asia: an evaluation of echolocation call frequency in discriminating between cryptic species. Acta Chiropterologica, 10: 221-242.

18. Soisook P., Niyomwan P., Srikrachang M., Srithongchuay T., Bates P. J. J., 2010. Discovery of Rhinolophus beddomei (Chiroptera: Rhinolophidae) from Thailand with a brief comparison to other related taxa. Tropical Natural History, 10(1): 69-79.

19. Talor P. J., Stoffberg S., Monadjem A, Shoeman M. C., Bayliss J., Cotterill P. P.
D., 2012. Four new bat species (Rhinolophus hildebrandtii complex) reflect plio-pleistocence divergence of dwarfs and giants across an Afromontane Archipelago. POS one, 7(9): 1-23.

20. Topal G., Csorba G., 1974. The subspecies division of Rhinolophus luctus Temminck, 1835, and the taxonomic status of R. beddomei Andersen, 1905 (Mammalia, Chiroptera). Miscellanea Zoologica Hungariaca, 7: 101-116.

21. Vu Dinh Thong, 2011. Systematics and echolocation of rhinolophoid bats (Mammalia: Chiroptera) in Vietnam. PhD Thesis, University of Tuebingen, Tuebingen, Germany, 258 pp.

22. Vu Dinh Thong, 2014. Acoustic identification and taxonomic remarks of horseshoe bats (Chiroptera: Rhinolophidae) in Cat Ba National Park, northeastern Vietnam. Proceedings of the first VASTBAS workshop on science and technology, Ha Long city, Vietnam: 323-328.

23. Vu Dinh Thong, Dietz C., Denzinger A., Bates P. J. J., Puechmaille S. J., Callou C., Schnitzler H.-U., 2012. Resolving a mammal mystery: the identity of Paracoelops megalotis (Chiroptera: Hipposideridae). Zootaxa, 3505, 75-85.

24. Vu Dinh Thong, Puechmaille S. J., Denzinger A., Bates P. J. J., Dietz C., Csorba G., Soisook P., Teeling E. C., Matsumura S., Furey N., Schnitzler H.U., 2012. Systematics of the Hipposideros turpis complex and a description of a new subspecies from Vietnam. Mammal Rev., 42: 166-192.

25. Vu Dinh Thong, Puechmaille S. J., Denzinger A., Dietz C., Csorba G., Bates P. J. J., Teeling E. C., Schnitzler H. U., 2012. A new species of Hipposideros (Chiroptera: Hipposideridae) from Vietnam. Journal of Mammalogy, 93: 1-11.

26. Wu Y., Motokawa M., Harada M., 2008. A new species of horseshoe bats of the genus Rhinolophus from China (Chiroptera: Rhinolophidae). Zoological Science, 25: 
438-443.

27. Wu Y., Harada M., Motokawa M., 2009. Taxonomy of Rhinolophus yunanensis Dobson, 1872 (Chiroptera: Rhinolophidae) with a description of a new species from Thailand. Acta Chiropterologica, 11: 237246.

28. Wu Y., Vu Dinh Thong, 2011. A new species of Rhinolophus (Chiroptera: Rhinolophidae) from China. Zoological Science, 28: 235-241.
29. Yoshiyuki M., Lim B. L., 2005. A new horshoe bat, Rhinolophus chiewkweeae (Chiroptera: Rhinolophidae), from Malaysia. Bulletin of the National Science Museum, Tokyo, Series A, 31: 29-36.

30. Zhou Z.-M., Servent A., Lim B. K., Eger J. L., Wang Y.-X., Jiang X.-L., 2009. A new species from Southwestern China in the Afro-Palearctic lineage of the horseshoe bats (Rhinolophus). Journal of Mammalogy, 90: $57-73$

\title{
ĐỊNH LOAI BẰNG TẦN SỐ SIÊU ÂM VÀ NHẬN XÉT VỀ ĐẶC ĐIỂM PHẦN LOẠI CỦA CÁC LOÀI DƠI LÁ MŨI VÀ NẾP MŨI (Chiroptera: Hipposideridae, Rhinolophidae) Ở VƯờn QUỐC GIA TAM ĐẢO, VÙNG ĐÔNG BẮC VIỆT NAM
}

\author{
Vũ Đình Thống
}

Viện Sinh thái và Tài nguyên sinh vật, Viện Hàn lâm KH\&CN Việt Nam

\section{TÓM TÁT}

Dơi nếp mũi và dơi lá mũi là tên phổ thông của những loài thuộc hai họ: Hipposideridae và Rhinolophidae. Tín hiệu tiếng kêu siêu âm của chúng đặc trưng bởi tiểu phần "tần số ổn định" (CF). Mỗi tín hiệu siêu âm của các loài dơi nếp mũi bao gồm hai tiểu phần ("tần số ổn định" và "dải tần số kết thúc") trong khi mỗi tín hiệu siêu âm của các loài dơi lá mũi bao gồm 3 tiểu phần ("dải tần số khởi đầu", "tần số ổn định" và "dải tần số kết thúc"). Từ năm 2008 đến 2014, nhiều đợt điều tra thực địa đã được thực hiện ở vườn quốc gia Tam Đảo với sự tập trung nghiên cứu về định loại và siêu âm của các loài dơi $\mathrm{CF}$. Kết quả điều tra cho thấy, vườn quốc gia Tam Đảo là nơi sinh sống của ba loài thuộc họ Hipposideridae (Hipposideros armiger, $H$. larvatus và $H$. pomona) và năm loài thuộc họ Rhinolophidae (Rhinolophus affinis, $R$. luctus, $R$. macrotis, $R$. pearsonii và $R$. pusillus). Trong quá trình điều tra, $R$. luctus chỉ được phát hiện trên cơ sở tiếng kêu siêu âm trong khi các loài còn lại được ghi nhận trên cơ sở định loại những cá thể mắt lưới hoặc bẫy. Tần số của họa âm thứ 2 (CF2) và đặc điểm hình thái của mỗi loài khác biệt hoàn toàn so với các loài còn lại. Bài báo này cung cấp những đặc điểm đặc trưng về hình thái và siêu âm của mỗi loài nhằm tạo cơ sở khoa học cho việc định loại trên thực địa, nâng cao kết quả điều tra, giám sát và bảo tồn các loài dơi $\mathrm{CF}$ ở vườn quốc gia trong thời gian tới.

Tù̀ khóa: Mammalia, bảo tồn, giám sát, phân loại học, siêu âm.

Ngày nhận bài: 14-6-2014 